\title{
KURIKULUM BELA NEGARA \\ SEBUAH KEBUTUHAN KURIKULUM SAAT INI DAN MASA DEPAN
}

\author{
Dedi M uhammad K urniawan ${ }^{1} \&$ Y uli Utanto ${ }^{2}$
}

\begin{abstract}
Abstrak: Bela Negara merupakan hak dan kewajiban warga negara sesuai dengan tuntunan UUD 1945. Bela Negara adalah salah satu sistem pertahanan rakyat semesta yang perlu dilakukan untuk dapat mengantisipasi segala macam ancaman yang kompleks dan multidimensional dalam usaha menghadapi ancaman saat ini dan ancaman di masa depan yang tentu akan berkembang sesuai dengan perkembangan jaman. Salah satu cara untuk dapat meratakan Bela Negara agar bisa diterima oleh seluruh warga negara Indonesia yaitu melalui pendidikan. Pelaksanaan Bela Negara dalam ruang lingkup pendidikan tidak akan terlaksana apabila tidak adanya payung kurikulum yang memuat tentang Bela Negara. Struktur kurikulum Bela Negara mengarah pada kompetensi yang diinginkan sesuai dengan ciri-ciri Bela Negara yang meliputi cinta tanah air, sadar berbangsa dan bernegara, yakin akan Pancasila sebagai ideologi negara, rela berkorban untuk bangsa dan negara, dan memiliki kemampuan Bela Negara. Untuk dapat menyempurnakan kurikulum Bela Negara yang dapat dijadikan landasan implementasi di Pendidikan formal tersebut maka diperlukan pengembangan kurikulum melalui adanya kerjasama antara kementerian terkait dan melibatkan ahli kurikulum beserta seluruh elemen terkait untuk dapat mengembangkan kurikulum Bela Negara.
\end{abstract}

K ata K unci: Kurikulum, Bela Negara, Kurikulum Bela Negara, Kurikulum Masa Depan

\footnotetext{
${ }^{1}$ Mahasiswa Pascasarjana Universitas Negeri Semarang dengan mengambil Prodi Kurikulum dan Teknologi Pembelajaran. Dapat dihubungi melalui email dedimuhammad19@ gmail.com

${ }^{2}$ Dosen Universitas Negeri Semarang. Dapat dihubungi melalui email utanto1979@mail.unnes.ac.id
} 


\section{Pendahuluan}

Pada era globalisasi saat ini tentu bukan suatu hal yang tidak mungkin bahwa bangsa Indonesia mempunyai Ancaman, Gangguan, Hambatan, dan Tantangan (AGHT) yang nyata. Sebab, keamanan di era global ini bersifat dinamis, yang berarti bangsa Indonesia bisa saja mempunyai ancaman yang datang dari dalam maupun luar negeri yang bisa mengancam keutuhan Negara Kesatuan Republik Indonesia.

Dinamika ancaman saat ini sangat kompleks dan multidimensional. Ancaman militer, ancaman non-militer, bahkan ancaman hibrida dapat dikategorikan dalam bentuk nyata maupun belum nyata. Wujud ancaman tersebut diantaranya radikalisme, separatisme dan pemberontakan bersenjata, bencana alam, pelanggaran wilayah perbatasan, perompakan dan pencurian kekayaan alam, wabah penyakit, serangan siber dan spionase, peredaran dan penyalahgunaan narkoba, serta konflik terbuka atau perang konvensional. Kondisi dalam negeri juga tidak dapat dilepaskan dari pengaruh lingkungan strategis yang dipacu oleh faktor ideologi, politik, ekonomi, sosial budaya, dan keamanan ${ }^{3}$.

\footnotetext{
3 Buku Putih Pertahanan Indonesia 2015, Kementrian Pertahanan Republik Indonesia, hal: 1
}

Apabila ancaman-ancaman tersebut tidak dapat diantisipasi sedini mungkin, maka akan berimbas pada pudarnya nasionalisme dan melemahnya ideologi bangsa karena pengaruh ideologi negara lain yang tidak sesuai dengan nilai-nilai Pancasila yang dapat mempengaruhi lemahnya sistem pertahanan negara sehingga dapat ditembus oleh negara lain yang mempunyai kepentingan untuk memecah belah bangsa Indonesia. Oleh karenanya, diperlukan sebuah solusi untuk dapat mengatasi ancaman-ancaman tersebut serta dapat meminimalisir terjadinya hal-hal lain yang tidak diinginkan dalam upaya mengganggu kedaulatan NKRI salah satunya melalui Bela Negara.

Dasar hukum Bela Negara mengacu pada Undang Undang Dasar 1945 yang mengatakan bahwa "setiap warga negara berhak dan wajib ikut serta dalam upaya pembelaan negara ${ }^{4}$. . Hal ini menunjukan bahwa setiap unsur masyarakat Indonesia dituntut untuk mempunyai sikap Bela Negara dalam upaya menjaga dan melindungi segenap bangsa dan seluruh tumpah darah Indonesia apabila terdapat ancaman yang dapat merenggut kedaulatan Indonesia. Bela Negara merupakan pertahanan negara yang dilaksanakan melalui sitem

\footnotetext{
${ }^{4}$ Undang - Undang Dasar 1945 Pasal 27 Ayat 3
} 
pertahahan dan keamanan rakyat semesta (sishankamrata) yang menempatkan TNI sebagai kekuatan utama dan rakyat sebagai komponen cadangan dan pendukung, dimana setiap warga negara mempunyai kewajiban untuk ikut serta dalam usaha pertahanan negara 5 .

Penyiapan seluruh komponen sumber daya nasional yang mengarah pada rakyat dalam mencipatakan sistem pertahanan dan keamanan rakyat semesta (sishankamrata) harus dapat terlaksana secara menyeluruh kepada setiap unsur masyarakat yaitu salah satunya melalui program pendidikan yang berbasis pada Bela Negara. Penanaman nilai nilai Bela Negara dalam ruang lingkup pendidikan tak lain sebagai doktrin ideologi negara yang bersifat menyeluruh terutama bagi kalangan pendidikan formal.

Adanya penanaman nilai-nilai pendidikan Bela Negara di setiap jenjang pendidikan formal merupakan sebuah upaya dalam meningkatkan nasionalisme terutama di kalangan generasi muda serta dapat membekali kemampuan Bela Negara bagi para siswa maupun siswi yang dapat mempunyai indikator kecintaan kepada tanah air dalam upaya menempuh cita-cita bangsa Indonesia. Mencegah adanya

5 Siahaan, T. Bela Negara dan Kebijakan Pertahanan. WIRA. Jakarta: Pusat Komunikasi Publik Kementrian Pertahanan Republik Indonesia, hal: 8 pengaruh radikalisme di kalangan pemuda generasi bangsa serta mencegah mengikisnya nasionalisme. Namun, penyelenggaraan Pendidikan Bela Negara di setiap jenjang pendidikan formal masih belum bisa terlaksanakan sepenuhnya secara menyeluruh. Hanya sekolahsekolah yang berada di bawah naungan TNI saja yang menerapkan Pendidikan Bela Negara. Hal tersebut mengingat bahwa dalam pelaksanaanya masih sangat terbatas dan masih sebagai wacana dan tentu saja dari segi kebijakan belum menyentuh sepenuhnya ke dalam Pendidikan terutama dari segi kurikulumnya. Beranjak dari sini, salah satu upaya yang sangat perlu dilakukan adalah dengan merekonstruksi ulang konsep kurikulum agar diterapkannya Pendidikan Bela Negara disetiap jenjang Pendidikan formal sampai pada Perguruan Tinggi. Dalam kaitan ini maka pengembangan model kurikulum yang berbasis pada Pendidikan Bela Negara perlu diwujudkan.

\section{Ancaman Bangsa Indonesia}

Perkembangan dalam bidang teknologi bagaikan dua mata pisau yang satu bisa untuk memajukan bangsa Indonesia dan yang satu bisa menjadi ancaman serius bagi bangsa Indonesia. Salah satu dari dampak dan pengaruh tersebut bisa kita lihat melalui adanya 
kebebasan dan keterbukaan dalam menyampaikan pendapat ditambah dengan adanya kemudahan komunikasi melalui berbagai media social. Kehadiran media sosial dapat menggeser nilai-nilai kepercayaan seseorang terhadap suatu kejadian melalui berita-berita palsu (hoax) yang dapat menjadikan seseorang tersebut mudah terpercaya dan terprovokasi yang pada akhirnya orang tersebut akan merasa benci terhadap individu maupun kelompok lain yang tidak sepaham dengannya.

Media sosial telah memengaruhi kehidupan sosial dalam masyarakat. Perubahan-perubahan dalam hubungan sosial (social relationship) atau sebagai perubahan terhadap keseimbangan (equilibrium) hubungan sosial dan segala bentuk perubahan-perubahan pada lembaga-lembaga kemasyarakatan di dalam suatu masyarakat, yang mempengaruhi sistem sosialnya, termasuk di dalamnya nilai-nilai sikap dan pola perilaku di antara kelompok-kelompok dalam masyarakat ${ }^{6}$.

Indonesia merupakan negara pluralisme yang berarti bahwa Indonesia mempunyai berbagai macam keragaman yang terdiri dari berbagai macam agama, suku, ras, maupun golongan. Data hasil Sensus Penduduk pada tahun 2010 yang

\footnotetext{
${ }^{6}$ Cahyono, A. S. Pengaruh Media Sosial Terhadap Perubahan Sosial Masyarakat di Indonesia. "J urnal Unita", Vol 9 No 1: hal 140-157.
}

dilakukan oleh Badan Pusat Statistik tentang struktur dan komposi penduduk menurut kelompok suku bangsa yang menghasilkan bahwa jumlah suku bangsa yang ada di Indonesia secara keseluruhan mencapai 1.300 suku bangsa. Bahasa juga memiliki berbagai macam keberagaman. Hasil data BPS menyebutkan bahwa terdapat 2.500 jenis Bahasa yang ada di Indonesia, jumlah jenis Bahasa ini hampir dua kali lipat dari jumlah jenis suku bangsa yang mencapai sebanyak $1.340^{7}$.

Dari keberagaman yang berada dalam bingkai bangsa Indonesia tentu akan mengakibatkan terjadinya gesekan yang dapat mengarah pada suatu konflik, namun disisi lain bahwa keberagaman akan menjadikan bangsa ini lebih besar karena terkenal dengan kemajemukannya. Salah satu sumber konflik yang rentan muncul di tengah-tengah masyarakat yang beragam adalah konflik yang bersumber dari perbedaan agama ${ }^{8}$. Hal in juga diperkuat oleh pandangan yang di utarakan oleh Huttington bahwa perbedaan atau keragaman akan selalu memunculkan pertikaian dan konflik $^{9}$. Ancaman saat ini

\footnotetext{
7 Na'im, A. \& Syaputra, H. Kewarganegaraan, Suku Bangsa, Agama dan Bahasa Sehari-Hari Penduduk "Indonesia Hasil Sensus Penduduk 2010. Jakarta: Badan Pusat Statistik, hal: 8-11

${ }^{8}$ Hermawati, R., Paskarina, C., \& Runiawati, N. Toleransi Antar Umat Beragama di Kota Bandung, "U mbara: Indonesian Journal of Anthropology", Vol 1 No 2, hal: 105-124

9 Hutington, S. P. The Clash of Civilization. "F oreign Affairs". Vol 72, No 3, hal: 22-49
} 
bagi bangsa Indonesia yang majemuk dilihat dari sisi agamanya maka yang menjadi pointnya yaitu masalah intoleransi.

Tidak hanya isu tentang intoleransi yang menjadi pokok permasalahan di Indonesia saat ini, di sisi lain ada isu-isu radikalisme yang sedang berkembang di Indonesia. Munculnya radikalisme di Indonesia disebabkan oleh perkembangan di tingkat global dilihat dari situasi yang kacau di negara-negara Timur Tengah khususnya Afghanistan, Palestina, Irak, Yaman, Mesir, Suriah, dan Turki dipandang oleh kelompok radikal sebagai akibat campur tangan Amerika, Israel, dan sekutunya. Selain itu, kekacauan di negara-negara tersebut disebabkan oleh penyebaran paham wahabisme yang mengagungkan budaya Islam ala arab yang konservatif. Paham tersebut juga disebarkan ke Indonesia sehingga telah ikut mendorong timbulnya kelompok eksklusif yang sering menuduh orang lain yang berada di luar kelompok mereka sebagai musuh, kafir, dan boleh di perangi ${ }^{10}$.

Konflik yang sedang terjadi di Irak dan Suriah yang di dalangi oleh ideologi ISIS (Islamic State Iraq and Syria) bukan

10 Asrori, A. Radikalisme di Indonesia: Antara Historisitas dan Antropisitas. "Kalam: J urnal Studi Agama dan Pemikiran Islam", Vol 9 No 2 hal 253268. suatu ketidak mungkinan akan merembet ke Indonesia jika memang penanganan untuk menangkal ideologi tersebut lemah. Cita-cita ISIS adalah untuk mendirikan kekhalifahan Islam di Irak dan Suriah. Dalam upaya mewujudkan tujuannya ISIS menyebarkan ideologinya melalui beragam propaganda untuk menarik simpatisan dari berbagai macam manca negara, terutama Indonesia. Masuknya paham ISIS tidak terlepas dari persentuhannya dengan kelompok yang memiliki cita-cita revivalisme Islam yang sebelumnya telah lama hadir di Indonesia ${ }^{11}$.

Ancaman lain yang datang dari dalam negeri seperti dengan adanya gerakan separatis bersenjata, penyalahgunaan narkoba, korupsi, kemiskinan, kesenjangan social, dan masih banyak lagi lainnya yang tentu saja hal tersebut akan mengancam keutuhan NKRI. Bukan hanya ancaman dalam negeri saja yang menjadi sorotan namun ada pula ancaman yang datang dari luar negeri yang tentunya akan berimbas pada kedaulatan NKRI, seperti halnya konflik Laut China Selatan (LCS) karena hegemoni Tiongkok yang ingin menguasai Laut China Selatan dan menyeret negara-negara Asia Tenggara terutama Indonesia yang terkena

\footnotetext{
${ }^{11}$ Rijal, N. K. Eksistensi dan Perkembangan ISIS: Dari Irak Hingga Indonesia, "Jurnal Ilmiah Hubungan Internasional, Vol 13 No 1, hal: 45-60
} 
dampaknya akibat perairan natuna masuk ke dalam "klaim 9 garis". Hal tersebut telah diperkuat oleh Yee yang mengatakan adanya sebuah kepastian dan stabilitas telah meningkat di Laut China Selatan ${ }^{12}$.

Ancaman yang datang dari luar negeri dapat berupa pelanggaran wilayah yang meliputi udara, laut, dan darat. Serta adanya masalah perbatasan dengan negaranegara tetangga yang belum selesaiselesai, adanya penyelundupan narkoba dan imigran gelap, spionase, sabotase, dan agresi militer negara lain walupun ini memang sangat kecil kemungkinan akan terjadi. Ancaman saat ini perlu diantisipasi untuk dapat dihadapi apabila hal tersebut terjadi, adapun ancaman di masa yang akan datang tentu akan berubah bahkan akan berkembang lebih kompleks seiring dengan perkembangan global yang terjadi.

\section{Kurikulum}

Sejumlah pengertian terkait mengenai kurikulum dapat merujuk pada sejumlah sumber seperti halnya Saylor dan Alexander yang merumuskan kurikulum sebagai keseluruhan usaha yang dilakukan oleh lembaga pendidikan atau sekolah untuk mencapai tujuan yang telah ditetapkan, sementara Smith mengartikan sebagai seperangkat usaha dan upaya

12 Yee, A. Maritime Territorial Disputes in East Asia: A Comparative Analysis of the South China Sea and the East China Sea. "J ournal of Current Chinese Affairs". Vol 40. No 2, hal: 165-193 pendidikan agar siswa memiliki kemampuan hidup di masyarakat, Harold Rugg sendiri mengartikannya sebagai program sekolah yang di dalamnya terdapat semua siswa dan pekerjaan baru, Hilda Taba lebih ringkas dalam merepresentasi kurikulum sebagai perencanaan pembelajaran ${ }^{13}$.

Kurikulum dibagi ke dalam 2 kelompok yaitu pandangan lama dan pandangan baru. Pandangan lama atau yang disebut sebagai pandangan tradisional merumuskan bahwa kurikulum adalah sejumlah mata pelajaran yang harus ditempuh murid untuk dapat memperoleh ijazah. Sedangkan pandangan baru merumuskan bahwa kurikulum adalah semua kegiatan, aktivitas, dan pengalaman yang terorganisir yang dimiliki oleh siswa di bawah arahan sekolah, baik di kelas maupun di luar kelas ${ }^{14}$. Dari perkembangan pandangan tersebut sudah tentu bahwa kurikulum berjalan sesuai dengan perkembangan teori dan praktik dalam Pendidikan.

Undang-undang Sisdiknas tahun 2003 Pasal 1 ayat 9 menyebutkan kurikulum sebagai seperangkat rencana dan pengaturan mengenai isi dan bahan

\footnotetext{
13 Hamid, H. Pengembangan Kurikulum Pendidikan. Bandung: Pustaka Setia, hal: 15-16

${ }^{14}$ Hamalik, O. 2013. Dasar-D asar Pengembangan Kurikulum. Bandung: Remaja Rosdakarya, hal: 3-4
} 
pelajaran serta cara yang digunakan sebagai pedoman penyelenggaraan kegiatan pembelajaran untuk mencapai tujuan pendidikan tertentu ${ }^{15}$.

Model pengembangan kurikulum sudah banyak yang telah ditawarkan oleh para ahli, namun dalam menyikapi hal ini ada beberapa model pengembangan kurikulum yang bisa dijadikan sebagai acuan yaitu model administrasi dan grass root. Model pengembangan Administrasi digunakan dalam sistem pengelolaan pendidikan atau kurikulum yang bersifat sentralisasi, sedangkan model Grass Root akan berkembang dalam sistem pendidikan yang bersifat desentralisasi ${ }^{16}$. Sentralisasi artinya kurikulum dikembangkan oleh pemerintah, sedangkan Grass Root diambil dari sekolah yang telah menerapkan kurikulum sebagai percontohan dalam mengembangkan kurikulum

\section{Bela Negara}

Undang-Undang Nomor 2 Tahun 2002 mengartikan bahwa Bela Negara adalah Sikap dan perilaku warga negara yang dijiwai oleh kecintaannya kepada Negara Kesatuan Republik Indonesia yang berdasarkan Pancasila dan UndangUndang Dasar 1945 dalam menjamin

15 Undang-Undang Republik Indonesia Nomor 20 Tahun 2003 tentang Sistem Pendidikan Nasional.

16 Sukmadinata, N. S., 2009. Pengembangan Kurikulum Teori dan Praktek. Bandung: Remaja Rosdakarya, hal:162-163 kelangsungan hidup bangsa dan negara ${ }^{17}$. Bela Negara atau pembelaan negara adalah tekad, sikap, dan tindakan warga negara yang teratur, menyeluruh, terpadu, dan berlanjut yang dilandasi oleh kecintaan pada tanah air serta kesadaran hidup berbangsa dan bernegara $^{18}$. Upaya Bela Negara dapat dilakukan oleh seluruh rakyat melalui pengabdian sesuai dengan profesinya masing-masing yang pada hakikatnya kegiatan pembelaan negara merupakan usaha dari warga negara untuk dapat mewujudkan ketahanan nasional ${ }^{19}$.

Sesuai dengan amandemen UUD 1945 pasal 27 ayat 3 menjelaskan bahwa usaha Bela Negara merupakan hak dan kewajiban setiap warga negara. Hal ini menunjukkan adanya asas demokrasi dalam pembelaan negara yang mencakup dua arti. Pertama, bahwa setiap warga negara turut serta dalam menentukan kebijakan tentang pembelaan negara melalui lembaga-lembaga perwakilan sesuai dengan UUD 1945 dan perundangundangan yang berlaku. Kedua, bahwa setiap warga negara harus turut serta dalam setiap usaha pembelaan negara,

\footnotetext{
17 Undang-Undang Republik Indonesia Nomor 2 Tahun 2002 tentang Kepolisian

18 Kaelan. \& Zubaidi, A,. Pendidikan Kewarganegaraan untuk Perguruan Tinggi. Yogyakarta: Paradigma, hal: 182

19 Winarno. Paradigma Baru Pendidikan Kewarganegaraan, Panduan Kuliah di Perguruan Tinggi. Jakarta: Bumi Aksara, hal: 182
} 
sesuai dengan kemampuan dan profesinya masing-masing ${ }^{20}$.

5. Urgensi Kurikulum Pendidikan Bela Negara

Upaya Bela Negara harus dilakukan dalam rangka pembinaan kesadaran Bela Negara bagi seluruh warga negara Indonesia agar memiliki kemampuan dalam memahami dan menghayati serta yakin untuk dapat menunaikan atas hak dan kewajibannya sebagai warga negara. Bela Negara pada hakikatnya merupakan unsur pertahanan yang bersifat semesta yang didasarkan pada hak dan kewajiban seluruh warga negara serta keyakinan akan kekuatan sendiri untuk mempertahankan kelangsungan hidup bangsa dan negara Indonesia yang merdeka dan berdaulat demi terciptanya negara yang damai dan sejahtera dalam menyongsong peradaban yang unggul dan mulia.

Sistem pertahanan yang bercirikan kerakyatan mengandung unsur bahwa orientasi pertahanan diabdikan oleh dan untuk kepentingan seluruh rakyat, sedangkan ciri pertahanan kesemestaan mengandung makna bahwa seluruh sumber daya nasional didayagunakan bagi upaya pertahanan, di sisi lain ciri

${ }^{20}$ Sukaya, E. dkk. Pendidikan Kewarganegaraan. Yogyakarta: Paradigma, hal: 10 pertahanan kewilayahan mengandung makna bahwa gelar kekuatan pertahanan dilaksanakan secara menyebar di seluruh wilayah NKRI sesuai dengan kondisi geografis Indonesia sebagai negara kepulauan $^{21}$.

Usaha pertahanan negara dibangun untuk dapat melindungi seluruh tumpah darah bangsa Indonesia, maka sudah selayaknya Bela Negara dijadikan sebagai unsur pertama yang harus dimiliki oleh setiap warga negara Indonesia. Dimana hal ini mengacu pada pola ancaman saat ini yang bisa saja akan mengganggu kedaulatan negara Indonesia, sedangkan ancaman di masa depan sudah tentu akan terjadi secara kompleks seiring dengan perkembangan jaman maka akan berkembang pula ancaman tersebut. Pendidikan Bela Negara bagi Pendidikan formal merupakan salah satu cara yang ampuh dalam menanamkan nilai-nilai Bela Negara bagi seluruh regenerasi bangsa Indonesia, yang tentunya pelaksanaan Bela Negara di ruang lingkup Pendidikan formal membutuhkan pondasi yang sangat kuat yaitu melalui adanya kurikulum khusus tentang Bela Negara.

Upaya Bela Negara yang merupakan hak dan kewajiban setiap

21 Pasaribu, R. B. F. Pendidikan Kewarganegaraan. Jakarta: Staffsite Universitas Gunadarma, hal: 121 
warga negara, dapat diimplementasikan dalam berbagai lingkungan di masyarakat salah satunya melalui Pendidikan formal yang dilakukan melalui Pendidikan Pendahuluan Bela Negara, yang bertujuan mempersenjatai warga negara secara psikis/mental dengan ideologi Pancasila, kecintaan pada tanah air, kerelaan berkorban untuk bangsa, negara serta kesadaran akan hak dan kewajibannya sebagai warga negara yang bertanggungjawab ${ }^{22}$.

Sasaran upaya Bela Negara adalah terwujudnya warga negara yang mengerti, menghayati, dan yakin untuk menunaikan kewajibannya dalam Bela Negara, dengan ciri-ciri; (1) cinta tanah air, (2) sadar berbangsa dan bernegara, (3) yakin akan Pancasila sebagai ideologi negara, (4) rela berkorban untuk Bangsa dan Negara, dan (5) memiliki kemampuan Bela Negara ${ }^{23}$.

\section{Struktur Kurikulum Bela Negara}

Upaya pengintegrasian Bela Negara ke dalam pendidikan formal dapat dilakukan dengan menyusun perencanaan kurikulum yang dilakukan dengan membuat susunan struktur kurikulum yang mengacu pada kurikulum berbasis Bela Negara.

\footnotetext{
${ }^{22}$ Subagyo, dkk, Pendidikan Kewarganegaraan.

Semarang: UPT Unnes Press, hal: 41

23 Andrianto, T. T. Paradigma Baru Bela Negara Implementasi dan Pengembangannya di Era Globalisasi. Yogyakarta: Global Pustaka Utama, hal: $109-110$
}

Struktur kurikulum akan menggambarkan konseptualisasi konten kurikulum dalam bentuk mata pelajaran, distribusi konten mata pelajaran dalam semester atau tahun, serta beban belajar untuk setiap peserta didik. Struktur kurikulum juga merupakan aplikasi konsep pengorganisasian konten dalam sistem belajar dan pengorganisasian beban belajar dalam sistem pembelajaran ${ }^{24}$.

Isi konten atau materi pada Bela Negara dapat disesuaikan dengan kompetensi yang ingin dicapai dan mengarah yang pada ciri-ciri Bela Negara itu sendiri, dibawah ini akan disebutkan beberapa materi dari kurikulum Bela Negara yang dapat dijadikan sebagai acuan dalam mengembangan kurikulum Bela Negara.

Tabel 1. Struktur Kurikulum Bela Negara ${ }^{25}$

\begin{tabular}{|c|c|c|}
\hline No & $\begin{array}{l}\text { Sosok } \\
\text { I deal }\end{array}$ & M ateri \\
\hline \multirow[t]{3}{*}{1} & \multirow{3}{*}{$\begin{array}{l}\text { Mencintai } \\
\text { Tanah Air }\end{array}$} & Sejarah Kebangsaan \\
\hline & & Kepemimpinan \\
\hline & & $\begin{array}{l}\text { Kearifan budaya } \\
\text { lokal }\end{array}$ \\
\hline \multirow[t]{4}{*}{2} & \multirow{4}{*}{$\begin{array}{l}\text { Sadar } \\
\text { berbangsa } \\
\text { dan } \\
\text { bernegara }\end{array}$} & Wawasan nusantara \\
\hline & & $\begin{array}{l}\text { Pengetahuan } \\
\text { kerukunan umat } \\
\text { beragama }\end{array}$ \\
\hline & & $\begin{array}{l}\text { Pengetahuan } \\
\text { terorisme, } \\
\text { sparatisme, dan } \\
\text { radikalisme }\end{array}$ \\
\hline & & Pengetahuan bahaya \\
\hline \multicolumn{3}{|c|}{24 Kementerian Pendidikan dan Kebudayaar } \\
\hline \multicolumn{3}{|c|}{$\begin{array}{l}\text { Kurikulum 2013: Kompetensi Dasar Sekola } \\
\text { M enengah Atas (SM A) dan Madrasah Aliyah (M A } \\
\text { 2013, hal:6 }\end{array}$} \\
\hline
\end{tabular}




\begin{tabular}{|c|c|c|}
\hline & & narkoba \\
\hline \multirow[t]{2}{*}{3} & \multirow{2}{*}{$\begin{array}{l}\text { Meyakini } \\
\text { Pancasila } \\
\text { sebagai } \\
\text { ideologi } \\
\text { negara }\end{array}$} & $\begin{array}{l}\text { Empat pilar } \\
\text { kebangsaan }\end{array}$ \\
\hline & & $\begin{array}{l}\text { Pendidikan } \\
\text { pancasila }\end{array}$ \\
\hline \multirow[t]{3}{*}{4} & \multirow{3}{*}{$\begin{array}{l}\text { Rela } \\
\text { berkorban } \\
\text { untuk } \\
\text { bangsa dan } \\
\text { negara } \\
\end{array}$} & $\begin{array}{l}\text { Dinamika ancaman } \\
\text { bangsa Indonesia }\end{array}$ \\
\hline & & Pertahanan negara \\
\hline & & Ketahanan nasional \\
\hline \multirow[t]{6}{*}{5} & \multirow{6}{*}{$\begin{array}{l}\text { Memiliki } \\
\text { kemampuan } \\
\text { bela negara }\end{array}$} & $\begin{array}{l}\text { Tataran dasar bela } \\
\text { negara }\end{array}$ \\
\hline & & PBB \\
\hline & & $\mathrm{P} 3 \mathrm{~K}$ \\
\hline & & $\begin{array}{l}\text { Penanggulangan } \\
\text { bencana }\end{array}$ \\
\hline & & Outbound \\
\hline & & $\begin{array}{l}\text { Pengetahuan senjata } \\
\text { api }\end{array}$ \\
\hline
\end{tabular}

Kurikulum pelaksanan Bela Negara dilakukan dengan $70 \%$ di kelas dan $30 \%$ di luar kelas yang mencangkup kurikulum dasar, inti, dan tambahan ${ }^{26}$. Hal ini berarti dapat dikatakan bahwa $70 \%$ mengarah pada aspek kognitif dan afektif serta $30 \%$ mengarah pada psikomotor.

Pemilihan materi dalam Bela Negara yang diterapkan pada Pendidikan formal mengacu pada perkembangan psikologis peserta didik, seperti halnya SD, SMP, dan SMA. Tidak perlu adanya materi pengetahuan senjata api, namun SMA bisa dilakukan dengan hanya menggunakan replika senjata yang terbuat dari kayu atau lainnya.

\footnotetext{
${ }^{26}$ Nur Khafifah, Menhan: Progeam Bela Negara 70 Persen di Kelas, di akses dari https://news.detik.com/berita/3050572/menhanprogram-bela-negara-70-persen-di-kelas
}

Beban belajar Bela Negara pada Pendidikan formal dapat disesuaikan dengan beban belajar yang telah ditetapkan oleh Kementerian Pendidikan dan Kebudayaan dengan beban belajar siswa SD dan SMP 40 menit sedangkan untuk SMA 45 menit $^{27}$. Sedangkan untuk perguruan tinggi menggunakan sistem SKS dengan beban 160 menit $^{28}$.

\section{Kesimpulan}

Untuk dapat mengantisipasi segala macam ancaman bangsa Indonesia saat ini yang begitu kompleks dan multidimensional dan sebagai antisipasi dalam menghadapi ancaman masa depan yang tentunya akan terus berkembang sesuai dengan perkembangan jaman maka diperlukannya sebuah sistem pertahanan yang mengarah pada pertahanan rakyat semesta, dimana pertahanan tersebut melibatkan seluruh warga negara Indonesia melalui adanya pendidikan Bela Negara.

Pelaksanaan pendidikan Bela Negara akan lebih merata untuk seluruh warga negara Indonesia apabila masuk dalam ruang lingkup pendidikan formal. Namun pelaksanaan tersebut tidak akan berjalan tanpa adanya payung kurikulum yang memuat tentang Bela Negara, karena pada dasarnya kurikulum adalah jantung

27 Dokumen Kurikulum 2013, Kementerian dan Kebudayaan Republik Indonesia, hal: 13-17

${ }^{28}$ Permendikbud No 49 tahun 2014 tentang Standar Nasional Pendidikan Tinggi Pasal 15 Point 2 
dari pendidikan yang dapat dijadikan dasar dalam pelaksanaan proses belajar mengajar.

Sebagai pertimbangan dalam usaha pengembangan kurikulum Bela Negara bagi pendidikan formal maka salah satunya bisa mengacu pada model pengembangan kurikulum administrasi. Tentunya pengembangan kurikulum tersebut mempunyai sifat sentralisasi dimana pengembangan lebih dibebankan pada lembaga/kementrian terkait atau dengan menggunakan model Grass Root yang dapat mengembangkan kurikulum Bela Negara melalui sekolah atau Lembaga Pendidikan yang telah melaksanakan kurikulum Bela Negara diambil sebagai contoh untuk mengembangkan kurikulum Bela Negara. Struktur kurikulum Bela Negara mencangkup kurikulum dasar, inti, dan tambahan yang dituangkan dalam berbagai macam materi yang mengarah pada kompetensi yang di inginkan sesuai dengan ciri-ciri Bela Negara itu sendiri.

Pada kesempatan ini maka ada beberapa rekomendasi bagi Kementerian Pertahanan Republik Indonesia yang memiliki program 100 juta kader Bela Negara dan bagi Kementerian Pendidikan dan Kebudayaan Republik Indonesia serta Kementerian Riset, Teknologi, dan Pendidikan Tinggi Republik Indonesia yang meliputi:
1. Wacana adanya Bela Negara masuk dalam kurikulum Pendidikan harus segera terlaksana sesuai dengan program yang telah direncanakan.

2. Adanya kerjasama antara ketiga kementerian dalam mengembangkan kurikulm Bela Negara.

3. Melibatkan ahli kurikulum dan seluruh elemen yang terkait untuk dapat mengembangkan kurikulum Bela Negara.

\section{Daftar Pustaka}

Andrianto, T. T. 2015. Paradigma Baru Bela Negara Implementasi dan Pengembangannya di Era Globalisasi. Yogyakarta: Global Pustaka Utama.

Asrori, A. 2015. Radikalisme di Indonesia: Antara Historisitas dan Antropisitas. Kalam: "J urnal Studi Agama dan Pemikiran Islam", Vol 9 No 2: 253-268.

Buku Putih Pertahanan Indonesia. Cetakan Ketiga Tahun 2015. Kementrian Pertahanan Republik Indpnesia.

Cahyono, A. S. 2016. Pengaruh Media Sosial Terhadap Perubahan Sosial Masyarakat di Indonesia. "J urnal U nita", Vol 9 No 1: 140-157.

Dokumen Kurikulum 2013, Kementrian Pendidikan dan Kebudayaan Republik Indonesia.

Hamalik, O. 2013. Dasar-Dasar Pengembangan Kurikulum. Bandung: Remaja Rosdakarya. 
Hamid, H. 2012. Pengembangan Kurikulum Pendidikan. Bandung: Pustaka Setia.

Hermawati, R., Paskarina, C., \& Runiawati, N. 2016. Toleransi Antar Umat Beragama di Kota Bandung. "U mbara: Indonesian Journal of Anthropology", Vol 1 No 2: 105-124.

Hutington, S. P. 1993. The Clash of Civilization. "Foreign Affairs J ournal". Vol 72, No 3: 22-49.

Kaelan. \& Zubaidi, A,. 2007. Pendidikan Kewarganegaraan untuk Perguruan Tinggi. Yogyakarta: Paradigma.

Kafifah, N. 2015. Menhan: Program Bela Negara 70 Persen di Kelas. Diakses online dari https://news.detik.com/berita/3050 572/menhan-program-bela-negara70-persen-di-kelas

Kurikulum 2013: Kompetensi Dasar Sekolah Menengah Atas (SMA) / Madrasah Aliyah (MA). Kementrian Pendidikan dan Kebudayan Republik Indonesia.

Na'im, A. \& Syaputra, H. 2010. Kewarganegaraan, Suku Bangsa, Agama dan Bahasa Sehari-Hari Penduduk Indonesia Hasil Sensus Penduduk 2010. Jakarta: Badan Pusat Statistik.

Pasaribu, R. B. F. 2013. Pendidikan Kewarganegaraan. Jakarta: Staffsite Universitas Gunadarma.

Peraturan Menteri Pendidikan dan Kebudayaan Republik Indonesia Nomor 49 Tahun 2014 tentang Standar Nasional Pendidikan Tinggi.
Rijal, N. K. 2017. Eksistensi dan Perkembangan ISIS: Dari Irak Hingga Indonesia. "J urnal IImiah Hubungan Internasional". Vol 13. No 1: 45-60.

Siahaan, T. 2016. Bela Negara dan Kebijakan Pertahanan. "WIRA". Jakarta: Pusat Komunikasi Publik Kementrian Pertahanan Republik Indonesia.

Subagyo, dkk. 2004. Pendidikan Kewarganegaraan. Semarang: UPT Unnes Press.

Sukaya, E. dkk. 2002. Pendidikan Kewarganegaraan. Yogyakarta: Paradigma.

Sukmadinata, N. S. 2009. Pengembangan Kurikulum Teori dan Praktek. Bandung: Remaja Rosdakarya.

Undang-Undang Dasar Negara Republik Indonesia Tahun 1945

Undang-Undang Republik Indonesia Nomor 2 Tahun 2002 tentang Kepolisian.

Undang-Undang Republik Indonesia Nomor 20 Tahun 2003 tentang Sistem Pendidikan Nasional.

Winarno. 2010. Paradigma Baru Pendidikan Kewarganegaraan, Panduan Kuliah di Perguruan Tinggi. Jakarta: Bumi Aksara.

Yee, A. 2011. Maritime Territorial Disputes in East Asia: A Comparative Analysis of the South China Sea and the East China Sea. "Journal of Current Chinese Affairs". Vol 40. No 2: 165-193. 